\title{
Comparison between Streptococcus macedonicus and Streptococcus waius strains and reclassification of Streptococcus waius (Flint et al. 1999) as Streptococcus macedonicus (Tsakalidou et al. 1998)
}

\footnotetext{
${ }^{1}$ Dipartimento di Scienze e Tecnologie Alimentari e Microbiologiche, sezione Microbiologia Industriale, University of Milano, Via Celoria 2, 20133 Milano, Italy

2 New Zealand Dairy Research Institute, Private Bag 11029, Palmerston North, New Zealand

${ }^{3}$ The Horticulture and Food Institute of New Zealand, Private Bag 11030, Palmerston North, New Zealand
}

\author{
P. L. Manachini, ${ }^{1}$ S. H. Flint, ${ }^{2}$ L. J. H. Ward, ${ }^{2}$ W. Kelly, ${ }^{3}$ M. G. Fortina, ${ }^{1}$ \\ C. Parini ${ }^{1}$ and Diego Mora ${ }^{1}$
}

Author for correspondence: Diego Mora. Tel: +39 02 58356701. Fax: + 390258356694. e-mail: diego.mora@unimi.it

Two species of dairy streptococci, Streptococcus waius and Streptococcus macedonicus, were originally characterized by 16S-23S intergenic spacer sequence analysis, random amplified polymorphic DNA fingerprinting, PFGE analysis and DNA-DNA reassociation experiments. All genetic data suggested that $S$. waius strains belong to the previously described species $S$. macedonicus. Likewise, the phenotypic characterization showed that strains of $S$. macedonicus and $S$. waius were highly related and easily differentiated from the closest phylogenetic neighbour, Streptococcus bovis, principally by their failure to produce a blackening reaction in medium containing aesculin. The utilization of maltose and cellobiose by $S$. macedonicus/S. waius strains allowed their differentiation from the most studied dairy species, Streptococcus thermophilus. On the basis of genetic and phenotypic data $S$. macedonicus and $S$. waius species should be considered synonyms and S. macedonicus has the priority.

Keywords: dairy streptococci, Streptococcus macedonicus, Streptococcus waius

\section{INTRODUCTION}

Thermophilic dairy streptococci have usually been identified as Streptococcus thermophilus or as ' $S$. thermophilus-like' (Moschetti et al., 1998; Flint et al., 1999) micro-organisms. The identification of dairy streptococci as $S$. thermophilus-like micro-organisms is principally due to their unusual carbohydrate fermentation pattern and/or their different genotype, compared with those of $S$. thermophilus strains. Furthermore, these unusual strains fail to produce a blackening reaction in medium containing aesculin, a characteristic which has allowed the discrimination of these dairy streptococci from the other dairy and nondairy Streptococcus species, such as Streptococcus salivarius, Streptococcus bovis, Streptococcus alactolyticus and Streptococcus equinus. Two species, Streptococcus macedonicus (Tsakalidu et al., 1998) and

Abbreviations: ITS, intergenic spacer; RAPD, random amplified polymorphic DNA.
Streptococcus waius (Flint et al., 1999) have been described which have allowed some clarification of the taxonomically undefined group of ' $S$. thermophiluslike' organisms. The dairy-associated $S$. macedonicus strains were isolated from the naturally fermented Greek Kasseri cheese and from sour mash, while $S$. waius strains were isolated from biofilms on stainless steel samples exposed to pasteurized skimmed milk and from dairy products from dairy manufacturing plants. On the basis of phenotypic characterization, $S$. macedonicus and $S$. waius are easily differentiated from $S$. thermophilus by their ability to produce acid from cellobiose, maltose, melibiose and raffinose. S. macedonicus and $S$. waius do not produce acid from aesculin, $\beta$-gentibiose and glycogen, and are bileintolerant, hence they are more closely related to $S$. thermophilus than to the other dairy streptococci. However they are phylogenetically located within the heterogeneous $S$. bovis rRNA group, whereas $S$. thermophilus is closely related to $S$. salivarius (Schleifer et al., 1991). 
The phenotypic descriptions of $S$. macedonicus and $S$. waius allow a clear discrimination of the two species from the other dairy streptococci, but in the same taxonomic descriptions it is hard to find significant phenotypic traits that allow the differentiation between these two species. The only exception is the $\beta$ galactosidase activity that was reported to be negative in $S$. macedonicus strains and positive in $S$. waius strains. Likewise, there are no comparable and available genetic data that allow discrimination between $S$. macedonicus and $S$. waius, with the exception of the $\mathrm{G}+\mathrm{C}$ content that is reported to be 38 and $34.6 \mathrm{~mol} \%$, respectively.

In this study we provide genotypic and phenotypic evidence that $S$. macedonicus and $S$. waius should be considered synonyms and that $S$. macedonicus has priority.

\section{METHODS}

Strains and laboratory media. Strains were routinely maintained at $4{ }^{\circ} \mathrm{C}$ after growth at $37^{\circ} \mathrm{C}$ for $18 \mathrm{~h}$ in M17 broth (Difco). For longer term maintenance, stock cultures were stored in $20 \%(\mathrm{v} / \mathrm{v})$ glycerol, $80 \%(\mathrm{v} / \mathrm{v}) \mathrm{M} 17$ at -20 and $-80{ }^{\circ} \mathrm{C}$. The strains used in this work and their origin are shown in Table 1. Carbohydrate fermentation was carried out using BSM medium containing chlorophenol red at a final concentration of $4 \%(\mathrm{w} / \mathrm{v})$ and the desired filtersterilized carbohydrate at a final concentration of $0.2 \%$ (w/v), as described by De Man et al. (1960). Acetoin production was evaluated as described by Lanyi (1987). Exopolysaccharide production was evaluated in ruthenium red milk plates consisting of $0.5 \%$ yeast extract, $10 \%$ skim milk powder, $1 \%$ sucrose, $1.5 \%$ agar and $0.08 \mathrm{~g}$ ruthenium red $1^{-1}$. Ruthenium red stains the bacterial cell wall producing red colonies for non-ropy strains and white colonies for ropy strains (Stingele et al., 1996).

DNA preparation. For the PCR reaction total DNA was extracted from $100 \mu$ of an overnight culture in M17 broth as described previously (Mora et al., 2000). For larger amounts of DNA, cells from an overnight culture in $100 \mathrm{ml}$ M17 broth were processed as described previously (Manachini et al., 1985). All the DNA solutions obtained were stored at $-20{ }^{\circ} \mathrm{C}$.

PCR experiments. Amplification of the $16 \mathrm{~S}-23 \mathrm{~S}$ intergenic spacer (ITS) region was performed in a volume of $25 \mu 1$ containing $1 \mu \mathrm{l}$ bacterial genomic DNA solution obtained as described above and about $100 \mathrm{ng}$ DNA, $2.5 \mu 110 \times$ PCR reaction buffer, $200 \mu \mathrm{M}$ each dNTP, $2.5 \mathrm{mM} \mathrm{MgCl}_{2}, 0.3 \mu \mathrm{M}$ each primer (ITSF, 5'-GTCGTAACAAGGTAGCCGTA3', and ITSR, 5'-CAAGGCATCCACCGT-3') (Mora et al., 1998) and 0.5 U Taq polymerase (Amersham Pharmacia). The temperature profile was as follows : 5 cycles of $94^{\circ} \mathrm{C}$ for $1 \mathrm{~min}, 55^{\circ} \mathrm{C}$ for $1 \mathrm{~min}$ and $72^{\circ} \mathrm{C}$ for $2 \mathrm{~min}$, and 30 cycles of $92{ }^{\circ} \mathrm{C}$ for $45 \mathrm{~s}, 60^{\circ} \mathrm{C}$ for 45 and $72{ }^{\circ} \mathrm{C}$ for $2 \mathrm{~min}$. Random amplified polymorphic DNA (RAPD) experiments with primers OPI02-mod (5'-GCTCGGAGGAGAGG-3') and AP2 (5'-AGTCAGCCAC-3') were performed in a final volume of $25 \mu \mathrm{l}$ using the following temperature profile with a modified ramp at $50 \%$ : primary DNA denaturation step at $94^{\circ} \mathrm{C}$ for 2 min followed by 5 cycles of $45 \mathrm{~s}$ at $94{ }^{\circ} \mathrm{C}, 45 \mathrm{~s}$ at $31^{\circ} \mathrm{C}$ and $2 \mathrm{~min}$ at $72{ }^{\circ} \mathrm{C} ; 35$ additional cycles were carried out increasing the annealing temperature to $40^{\circ} \mathrm{C}$. For all the amplification cycles the final extension was continued for $7 \mathrm{~min}$ at $72{ }^{\circ} \mathrm{C}$. The reproducibility of RAPD patterns was tested by repeating the analysis three times on

Table 1. Strains tested and their origin

\begin{tabular}{|c|c|c|}
\hline Species & Strain & Origin \\
\hline S. macedonicus & LMG 15061 & Sour mash; Tsakalidu et al. (1998) \\
\hline S. macedonicus & LMG 18487 & Greek Kasseri cheese; Tsakalidu et al. (1998) \\
\hline S. macedonicus & LMG $18488^{\mathrm{T}}$ & Greek Kasseri cheese; Tsakalidu et al. (1998) \\
\hline S. macedonicus & ASG $19 *$ & Asiago cheese, Italy \\
\hline S. macedonicus & ASG $38 *$ & Asiago cheese, Italy \\
\hline S. macedonicus & ASG $62 *$ & Asiago cheese, Italy \\
\hline S. macedonicus & ASG $69^{*}$ & Asiago cheese, Italy \\
\hline S. macedonicus & MON 30* & Montasio cheese, Italy \\
\hline S. waius & NZRCC $20100^{\mathrm{T}}$ & Biofilm on stainless steel; Flint et al. (1999) \\
\hline S. waius & $\mathrm{T}$ & Casein; Flint et al. (1999) \\
\hline S. waius & TLST2 & Pasteurized milk \\
\hline S. waius & TLST3 & Pasteurized milk \\
\hline S. waius & $7 \mathrm{c}$ & Biofilm on stainless steel; Flint et al. (1999) \\
\hline S. waius & $6 / 2$ & Biofilm on stainless steel; Flint et al. (1999) \\
\hline S. bovis & DSM $20480^{\mathrm{T}}\left(\right.$ ATCC $\left.33317^{\mathrm{T}}\right)$ & \\
\hline S. salivarius & DSM $20560^{\mathrm{T}}$ & \\
\hline S. salivarius & ATCC 13419 & \\
\hline S. equinus & NCTC 10386 & \\
\hline S. thermophilus & ATCC 19258 & \\
\hline S. thermophilus & DSM $20617^{\mathrm{T}}$ & \\
\hline L. lactis subsp. lactis & IL1403 & Le Bourgeois et al. (1992) \\
\hline
\end{tabular}

* Strains kindly provided by Dr Angiolella Lombardi, Veneto Agricoltura, Thiene, Italy. 
the same DNA template and also using DNA extracted at different stages of growth.

All amplification reactions were performed in a Gene Amp PCR System 2400 (Applera). Following amplification, $5 \mu 1$ of product was electrophoresed at $5 \mathrm{~V} \mathrm{~cm}^{-1}(1 \cdot 5-3 \%$ agarose gel, $0 \cdot 2 \mu \mathrm{g}$ ethidium bromide $\mathrm{ml}^{-1}$ ) in TAE buffer and photographed in UV light.

Computation of strain similarities. A computer similarity analysis of RAPD patterns was estimated by means of the Jaccard coefficient (Sneath \& Sokal, 1973) and clustering of strains was based on the unweighted pair group method with arithmetic averages (UPGMA). The NTSYS-PC computer program (version 1.30; Rohlf, 1987) was used in the data analysis.

16S-23S ITS. The ITS amplified products of strains LMG 18488 ${ }^{\mathrm{T}}$, LMG 15061, ASG 38, ASG 62 and MON 30, visualized by agarose gel electrophoresis, were excised from the gel using a Qiagen extraction kit and sequenced by using the dideoxy chain-termination method (Sanger et al., 1977) using ABI Prism BigDye technology in an ABI Prism 310 DNA sequencer (Applera). ITSF and ITSR were used as sequencing primers. The sequences obtained were manually aligned with the published $S$. waius, S. bovis and S. thermophilus ITS sequences.

Determination of DNA-DNA relatedness. DNA-DNA homology was determined as described previously (Manachini et al., 2000) by the optical renaturation rates method (Kurtzman et al., 1979) with a model Response spectrophotometer equipped with an Advance Kinetics Graphic Version 1.3 thermoprogrammer (CIBA-Corning Diagnostics). For all samples tested the melting temperature $\left(T_{\mathrm{m}}\right)$ was calculated in $5 \times \mathrm{SSC}$, the same salt concentration was used for the determination of DNA-DNA homology. The temperature of hybridization was $25^{\circ} \mathrm{C}$ below the $T_{\mathrm{m}}$ previously calculated. The equation of Seidler \& Mandel (1971) was used to calculate the extent of DNA-DNA reassociation.

$T_{\mathrm{m}}$ values for $S$. macedonicus and $S$. waius were also compared using the LightCycler (Roche) method of Xu et al. (2000).

PFGE. The procedure used to prepare genomic DNA in agarose blocks has been described by Kelly et al. (1993). DNA embedded in agarose was digested with the enzymes BssHII, I-CeuI or SmaI (New England Biolabs), loaded into the wells of $1 \%$ agarose gels (pulsed field certified agarose; Bio-Rad) and run at $200 \mathrm{~V}$ for $20 \mathrm{~h}$ at $14^{\circ} \mathrm{C}$ in $0.5 \times$ Trisborate buffer using a CHEF DR II PFGE apparatus and model 1000 mini chiller (Bio-Rad). Pulse times used were 1-20 s for BssHII, 1-30 s for SmaI and 5-50 s for I-CeuI. To determine the size of the largest fragments from I-CeuI digests, gels were prepared from $0.8 \%$ chromosomal grade agarose (Bio-Rad) and run with the pulse time ramped between 150 and 300 s. DNA prepared from Lactococcus lactis subsp. lactis IL1403 (Le Bourgeois et al., 1992) and Saccharomyces cerevisiae PFG markers (New England Biolabs) were used as size standards.

\section{RESULTS AND DISCUSSION}

\section{Phenotypic traits}

Phenotypic analysis of $S$. macedonicus and S. waius strains listed in Table 1 was carried out in comparison with S. thermophilus DSM $20617^{\mathrm{T}}$, S. salivarius DSM
$20560^{\mathrm{T}}$ and $S$. bovis DSM $20480^{\mathrm{T}}$ (Table 2). S. macedonicus and $S$. waius strains were all able to grow in M17 broth in the presence of $4 \% \mathrm{NaCl}$, while only $S$. waius strains showed growth in up to $6.5 \% \mathrm{NaCl}$. No growth was detected in the presence of $4 \% \mathrm{NaCl}$ for $S$. bovis DSM $20480^{\mathrm{T}}$ or $S$. salivarius DSM $20560^{\mathrm{T}}$. $S$. macedonicus and $S$. waius strains were able produce acid from D-glucose, galactose, D-fructose, D-mannose, sucrose, cellobiose and maltose. All S. macedonicus and $S$. waius strains, except strain LMG 15061 were also able to utilize raffinose and melibiose. These properties have been linked to a transposable element in L. lactis (Kelly et al., 1998) and if similarly arranged in $S$. macedonicus and $S$. waius could be relatively easily lost from a strain. All $S$. macedonicus and $S$. waius strains were negative when tested for acid production from glycogen and they failed to produce the blackening reaction in medium containing aesculin. The ability of $S$. macedonicus and $S$. waius to utilize galactose, maltose and cellobiose allowed their differentiation from $S$. thermophilus strains. Exopolysaccharide production was evaluated on ruthenium red milk where $S$. macedonicus and $S$. waius strains grew as white colonies.

In conclusion, the phenotypic characteristics analysed allowed an easy discrimination of $S$. macedonicus and $S$. waius strains from the closely related $S$. thermophilus, $S$. salivarius and $S$. bovis. It was not possible to detect phenotypic differences between $S$. macedonicus and $S$. waius strains with the exception of a moderately higher halotolerance shown by $S$. waius strains.

\section{Genotypic characterization}

The genetic characterization of Streptococcus species was carried out by comparing the 16S rDNA and ITS sequences, and evaluating the DNA-DNA homology values. Moreover, the genetic variability among $S$. macedonicus and $S$. waius strains was analysed by RAPD-PCR and PFGE experiments.

Phylogenetic analysis. The published 16S rDNA sequences of $S$. macedonicus LMG $18488^{\mathrm{T}}$ and $S$. waius NZRCC $20100^{\mathrm{T}}$ were compared to each other using the Sequence Similarity Matrix tool of the Ribosomal Database Project II (Maidak et al., 2001). The 16S rDNA sequence similarity between these two species was $99 \cdot 5 \%$. Likewise the $16 \mathrm{~S}-23 \mathrm{~S}$ rDNA ITS of S. macedonicus LMG $18487^{\mathrm{T}}$, LMG 15061, ASG 38, ASG 62 and M30 and the published ITS of $S$. waius NZRCC $20100^{\mathrm{T}}$ (Flint et al., 1999) were found to be identical. Sequence comparison showed that the main differences among the analysed species were located upstream and downstream of the highly conserved tRNA $^{\text {Ala }}$ gene. No ITS sequence variation was observed among $S$. macedonicus and S. waius dairy strains isolated from different geographical areas, specifically Northern Italy, Greece and New Zealand.

DNA-DNA reassociation experiments and $\mathbf{G}+\mathbf{C}$ content. To confirm the close genetic relationship of $S$. macedonicus and $S$. waius strains, DNA-DNA hybrid- 
Table 2. Metabolic traits of S. macedonicus, S. waius, S. thermophilus and S. bovis

Data in parentheses were obtained in this study; ND, not determined; +, positive; - , negative; v, variable among the analysed strains; w, weak growth.

\begin{tabular}{|c|c|c|c|c|c|}
\hline Characteristic & S. macedonicus* & S. waius $\dagger$ & $\begin{array}{l}\text { S. thermophilus } \\
\text { DSM } 20617^{\mathrm{T}} \uparrow\end{array}$ & $\begin{array}{l}\text { S. bovis DSM } \\
2^{20480^{\mathrm{T}} \dagger}+\end{array}$ & $\begin{array}{l}\text { S. salivarius } \\
\text { DSM 20560 }^{\mathrm{T}}\end{array}$ \\
\hline Glycerol & - & $\mathrm{v}$ & - & - & $(+)$ \\
\hline Glycogen & - & - & - & + & $(+)$ \\
\hline D-Arabinose & $(-)$ & - & - & - & $(+)$ \\
\hline Galactose & $(+)$ & + & - & + & $(+)$ \\
\hline D-Glucose & $(+)$ & + & + & + & $(+)$ \\
\hline D-Fructose & $(+)$ & + & + & + & $(+)$ \\
\hline D-Mannose & $(+)$ & + & + & $+(-)$ & $(+)$ \\
\hline N-Acetylglucosamine & $-(+)$ & + & + & + & $(+)$ \\
\hline Aesculin & $(-)$ & - & - & + & $(+)$ \\
\hline Salicin & (v) & + & - & + & $(+)$ \\
\hline Inulin & - & - & - & + & $(+)$ \\
\hline Cellobiose & + & + & - & + & $(+)$ \\
\hline Maltose & + & + & - & + & $(+)$ \\
\hline Lactose & $(+)$ & + & + & + & $(+)$ \\
\hline Melibiose & (v) & + & - & + & $(+)$ \\
\hline Sucrose & $(+)$ & + & + & + & $(+)$ \\
\hline D-Raffinose & (v) & + & - & + & $(+)$ \\
\hline \multicolumn{6}{|c|}{ Growth in presence of $\mathrm{NaCl}$} \\
\hline $4 \%$ & $(+)$ & + & - & - & $(-)$ \\
\hline $6.5 \%$ & (w) & + & - & - & $(-)$ \\
\hline $7 \%$ & $(-)$ & + & - & - & $(-)$ \\
\hline \multicolumn{6}{|l|}{ Production of: } \\
\hline Acetoin & + & $(+)$ & + & $(-)$ & $(-)$ \\
\hline Exopolysaccharide & $(+)$ & $(+)$ & $(-)$ & $(-)$ & ND \\
\hline
\end{tabular}

* Based on the description of Tsakalidu et al. (1998).

$\dagger$ Based on the descriptions of Flint et al. (1999) and Hardie (1986).

ization experiments were carried out among some representative strains of each species. Values of 90-100\% were obtained between $S$. waius NZRCC $20100^{\mathrm{T}}$, S. macedonicus LMG $18487^{\mathrm{T}}$ and S. macedonicus LMG 15061. Furthermore, a DNA-DNA reassociation value of $40 \%$ was found between $S$. macedonicus DSM $18487^{\mathrm{T}}$ and the closest phylogenetic neighbour $S$. bovis DSM $20480^{\mathrm{T}}$. These data confirm that S. macedonicus (Tsakalidu et al., 1998) and $S$. waius (Flint et al., 1999) belong to the same DNADNA homology group, well separated from the closest phylogenetically related species, $S$. bovis.

Melting curve comparisons using the LightCycler (Roche) produced $\mathrm{G}+\mathrm{C}$ values that were consistently lower than the published values, with $32.0 \mathrm{~mol} \%$ for $S$. macedonicus and $33.6 \mathrm{~mol} \%$ for $S$. waius, supporting the similarity between the two organisms. The $\mathrm{G}+\mathrm{C}$ content of $S$. bovis DSM $20480^{\mathrm{T}}$ (ATCC $33317^{\mathrm{T}}$ ) used as reference was $34.7 \mathrm{~mol} \%$.

RAPD-PCR analysis and computation of strain similarity. The genetic variability of $S$. macedonicus and $S$. waius strains and related Streptococcus species was analysed by RAPD analysis using the OPI02-mod primer. As shown in Fig. 1, S. macedonicus and $S$. waius strains formed a cluster characterized by two main amplified fragments of about 600 and $810 \mathrm{bp}$ and by a weaker amplified fragment of $250 \mathrm{bp}$. Amplified fragments ranging from 380 to $600 \mathrm{bp}$, and from 1400 to $1450 \mathrm{bp}$ allowed the identification of different genotypes among the S. macedonicus/waius homology group.

The RAPD analysis using the AP2 primer supported the above results, confirming the similarity between $S$. macedonicus and $S$. waius (data not shown).

A UPGMA dendrogram (Fig. 2) derived from similarity coefficients calculated by the Jaccard method on the RAPD patterns, showing the relationship among the analysed strains, revealed that $S$. macedonicus and $S$. waius were well separated from $S$. bovis DSM $20480^{\mathrm{T}}$ at a similarity level less than $5 \%$. New Zealand $S$. waius strains were clustered together at a similarity level of $71.2 \%$ and they were separated from the nearest $S$. macedonicus European isolates at a similarity level of $52 \%$. S. macedonicus strains isolated from cheeses from northern Italy and from Greek dairy products showed a high degree of diversity and were clustered in different groups. Interestingly, the 
(a)

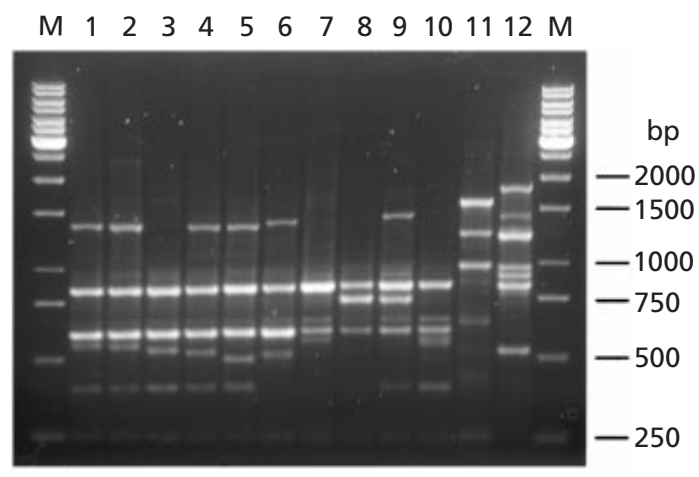

Fig. 1. Agarose gel electrophoresis showing the RAPD profiles obtained from $S$. macedonicus and $S$. waius strains and related streptococci using the OPI02-mod primer. Lanes: 1-5: S. waius NZRCC 20100', TLST3, TLST2, 7C and T, respectively; 6-10: S. macedonicus LMG 15061, LMG 18488 ${ }^{\top}$, LMG 18487, M30 and ASG 62, respectively; 11, S. bovis DSM 20480 ${ }^{\top} ; 12$, $S$. thermophilus DSM 20617 . M, molecular mass marker (GeneRuler 1 kb DNA Ladder; MBI Fermentas).

only vegetable-associated $S$. macedonicus strain, LMG 15061 , showed the lowest similarity value with the other strains of the same species (about $40 \%$ ).

PFGE analysis. PFGE data (Fig. 3) support the hypothesis that $S$. macedonicus and $S$. waius are the same species, since the banding patterns for digests with $B s s \mathrm{HII}$ and SmaI (which recognize random sites around the genome) are similar. The BssHII digests provide additional evidence that $S$. macedonicus $/ S$. waius are more closely related to $S$. bovis than they are to $S$. thermophilus.

DNA from strain LMG 18487 was not cut by SmaI, which suggests that the SmaI cutting site could be blocked by methylation and that this strain could carry a restriction-modification system. DNA from some L. lactis strains also fails to be cut with SmaI and most of these strains encode a methylase associated with the $S c r$ FI restriction-modification system (Davis et al., 1993; Ward \& Kelly, unpublished data). Restriction-modification or other bacteriophage defence mechanisms have not previously been reported for $S$. macedonicus or $S$. waius, but their presence in dairy environments implies that they are vulnerable to bacteriophage attack in the same way as other dairy bacteria.

The intron-encoded endonuclease I-CeuI recognizes a 19 bp sequence specific to all $23 \mathrm{~S}$ rRNA genes and so produces a number of restriction fragments which correspond to the number of rRNA operons on the chromosome. In accordance with the 16S rRNA data, the $S$. macedonicus and $S$. waius strains examined each have six copies of the rRNA genes and show the same $r r n$ genome organization. The chromosome size of the eight strains ranged between 2150 and $2250 \mathrm{~kb}$. This is considerably larger than the $S$. thermophilus chromosome which has previously been estimated at $\sim 1850 \mathrm{~kb}$ and which may have five or six copies of the rRNA genes (Roussel et al., 1997).

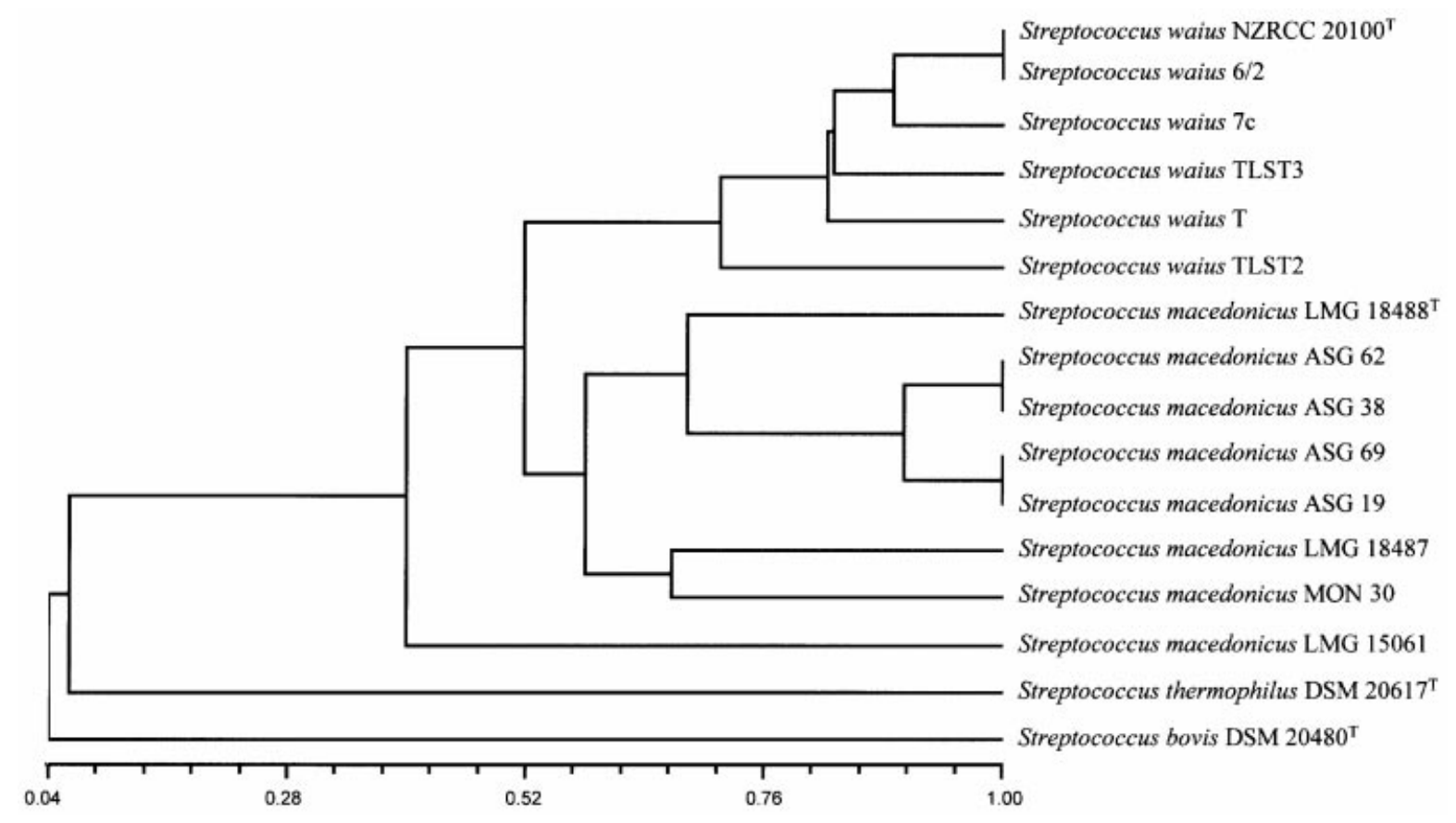

Fig. 2. UPGMA dendrogram derived from similarity coefficients calculated by the Jaccard method $\left(S_{\mathrm{j}}\right.$, shown on the scale at the bottom), showing the relationship among $S$. macedonicus, $S$. waius and related dairy streptococci analysed by RAPD using primers OPI02-mod and AP2. 
(a)

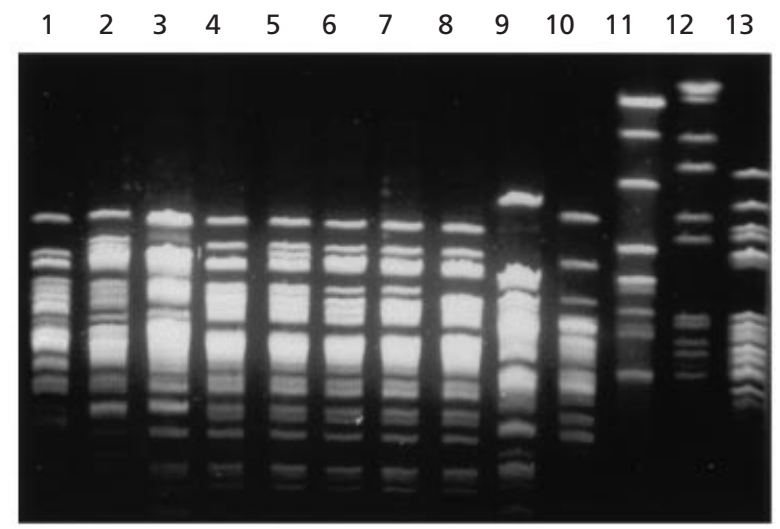

(b)

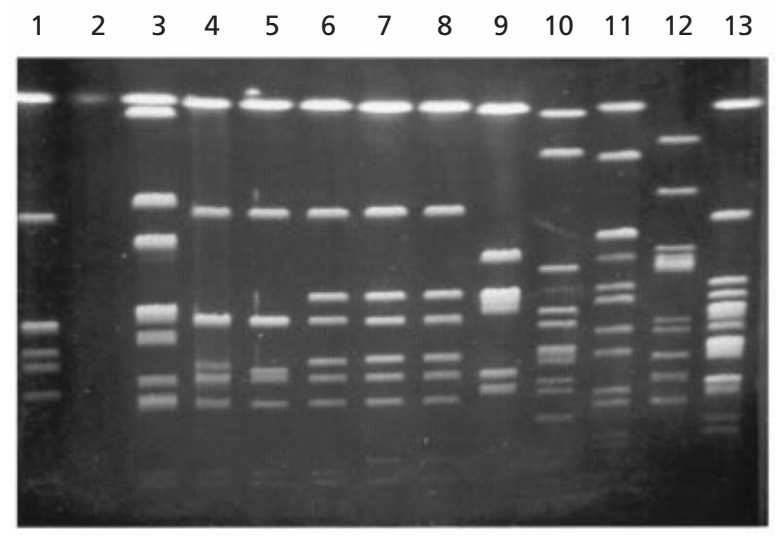

(c)

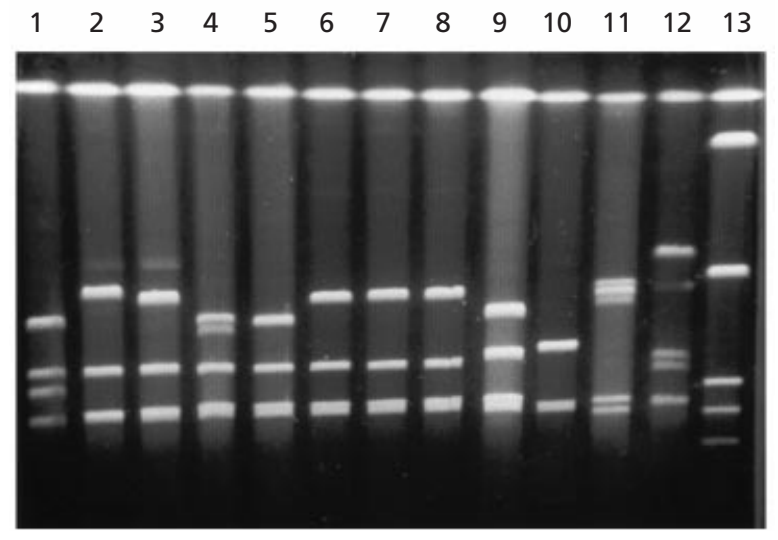

Fig. 3. PFGE analysis of Streptococcus species. Genomic DNA cut with BssHII (a), Smal (b) or I-Ceul (c). Lanes: 1-3, S. macedonicus LMG 15061, LMG 18487 and LMG 18488 , respectively; 4-8, S. waius 3/1, 7C, T, TLST2 and TLST3, respectively; 9 , S. bovis ATCC $33317^{\top} ; 10$, S. equinus NCTC 10386; 11 , S. salivarius ATCC 13419; 12, S. thermophilus ATCC 19258; 13, L. lactis subsp. lactis IL1403.

\section{Revision of the taxonomic position of S. waius}

In the present study, phenotypic and genotypic analysis carried out on S. macedonicus and S. waius strains suggest that they should be ascribed to the same species. Both the $16 \mathrm{~S}$ and the ITS sequences showed extremely high correlation between the two previously described taxa. Likewise, DNA-DNA reassociation values above $80 \%$ among $S$. macedonicus and $S$. waius strains confirmed that they belong to the same homology group. Moreover, the weak degree of variability observed in phenotypic characteristics (raffinose and melibiose fermentation) does not justify the allocation as two different species. We therefore suggest the reclassification of $S$. waius (Flint et al., 1999) as S. macedonicus (Tsakalidu et al., 1998).

\section{ACKNOWLEDGEMENTS}

We acknowledge Dr Angiolella Lombardi and Veneto Agricoltura, Thiene, Italy, for providing S. macedonicus strains isolated from traditional Italian cheese. We thank Dr Lorenzo Brusetti and Dr Lara Zamperini for their technical assistance. We thank Dr Lucy Skillman for her guidence in the use of the LightCycler and Kylie Walker for technical assistance. This research was supported by a grant of the Ministry of the University and Technological and Scientific Research (FIRST 2001).

\section{REFERENCES}

Davis, R., van der Lelie, D., Mercenier, A., Daly, C. \& Fitzgerald, G. F. (1993). ScrFI restriction-modification system of Lactococcus lactis subsp. cremoris UC503: cloning and characterization of two ScrFI methylase genes. Appl Environ Microbiol 59, 777-785.

De Man, J. C., Rogosa, M. \& Sharpe, M. E. (1960). A medium for the cultivation of lactobacilli. J Appl Bacteriol 23, 130-135.

Flint, S. H., Ward, J. H. \& Brooks, J. D. (1999). Streptococcus waius sp. nov., a thermophilic streptococcus from a biofilm. Int J Syst Bacteriol 49, 759-767.

Hardie, J. M. (1986). Genus Streptococcus Rosenbach 1884, $22^{\mathrm{AL}}$ In Bergey's Manual of Systematic Bacteriology, Vol. 2, pp. 1043-1071. Edited by P. H. A. Sneath, N. S. Mair, M. E. Sharpe \& J. G. Holt. Baltimore: Williams \& Wilkins.

Kelly, W. J., Huang, C. M. \& Asmundson, R. V. (1993). Comparison of Leuconostoc oenos strains by pulsed-field gel electrophoresis. Appl Environ Microbiol 59, 3969-3972.

Kelly, W. J., Davey, G. P. \& Ward, L. J. H. (1998). Conjugative transfer of raffinose metabolism in Lactococcus lactis. FEMS Microbiol Lett 167, 145-149.

Kurtzman, C. P., Johnson, C. J. \& Smiley, M. J. (1979). Determination of conspecificity of Candida utilis and Hansenula jadinii through DNA reassociation. Mycologia 71, 844-847.

Lanyi, B. (1987). Classical and rapid identification: methods for medically important bacteria. Methods Microbiol 19, 1-67.

Le Bourgeois, P., Lautier, M., Mata, M. \& Ritzenthaler, P. (1992). Physical and genetic map of the chromosome of Lactococcus lactis subsp. lactis IL1403. J Bacteriol 174, 6752-6762.

Maidak, B. L., Cole, J. R., Lilburn, T. G. \& 7 other authors (2001). The RDP-II (Ribosomal Database Project). Nucleic Acids Res 29, 173-174.

Manachini, P. L., Fortina, M. G., Parini, C. \& Craveri, R. (1985). Bacillus thermoruber sp. nov., nom. rev., a red-pigmented thermophilic bacterium. Int J Syst Bacteriol 35, 493-496.

Manachini, P. L., Mora, D., Nicastro, G., Parini, C., Stackebrandt, E., Pukall, R. \& Fortina, M. G. (2000). Bacillus thermodenitrificans sp. nov., nom. rev. Int J Syst Evol Microbiol 50, 1331-1337.

Mora, D., Fortina, M. G., Nicastro, G., Parini, C. \& Manachini, P. L. (1998). Genotypic characterization of thermophilic bacilli: a study on a new soil isolates and several reference strains. Res Microbiol 149, $711-722$. 
Mora, D., Fortina, M. G., Parini, C., Daffonchio, D. \& Manachini, P. L. (2000). Genomic subpopulations within the species Pediococcus acidilactici detected by multilocus typing analysis: relationship between pediocin AcH/PA-1 producing and non-producing strains. Microbiology 146, 2027-2038.

Moschetti, G., Blaiotta, G., Aponte, I., Catzeddu, P., Villani, F. \& Coppola, S. (1998). Random amplified polymorphic DNA and amplified ribosomal DNA spacer polymorphism - powerful methods to differentiate Streptococcus thermophilus strains. J Appl Microbiol 85, 25-36.

Rohlf, F. J. (1987). NTSYS-PC: Numerical taxonomy and multivariate analysis system for IBM PC microcomputer (and compatibles), version 1.30. New York: Applied Biostatistics.

Roussel, Y., Bourgoin, G., Guédon, G., Pébay, M. \& Decaris, B. (1997). Analysis of the genetic polymorphism between three Streptococcus thermophilus strains by comparing their physical and genetic organization. Microbiology 143, 1335-1343.

Sanger, F., Nicklen, S. \& Coulson, A. R. (1977). DNA sequencing with chain-terminating inhibitors. Proc Natl Acad Sci USA 74, 5463-5467.

Schleifer, K. H., Ehrmann, M., Krusch, U. \& Neve, H. (1991). Revival of the species Streptococcus thermophilus (ex. Orla-Jenson, 1919) nom. rev. Syst Appl Microbiol 14, 386-388.

Seidler, R. J. \& Mandel, M. (1971). Quantitative aspects of deoxyribonucleic acid renaturation: base composition, state of chromosome replication and polynucleotide homologies. J Bacteriol 106, 608-614.

Sneath, P. H. A. \& Sokal, R. R. (1973). Numerical Taxonomy: the Principles and Practice of Numerical Classification. San Francisco: Freeman.

Stingele, F., Neeser, J.-R. \& Mollet, B. (1996). Identification and characterization of the eps (exopolysaccharide) gene cluster from Streptococcus thermophilus Sfi6. J Bacteriol 178, 1680-1690.

Tsakalidou, E., Zoidou, E., Pot, B., Wassill, L., Ludwig, W., Devriese, L. A., Kalantzopoulos, G., Schleifer, K. H. \& Kersters, K. (1998). Identification of streptococci from Greek Kasseri cheese and description of Streptococcus macedonicus sp. nov. Int J Syst Bacteriol 48, 519-527.

Xu, H.-X., Kawamura, Y., Li, N., Zhao, L., Li, T.-M., Li, Z.-Y., Shu, S. \& Ezaki, T. (2000). A rapid method for determining the $\mathrm{G}+\mathrm{C}$ content of bacterial chromosomes by monitoring fluorescence intensity during DNA denaturation in a capillary tube. Int $J$ Syst Evol Microbiol 50, $1463-1469$. 